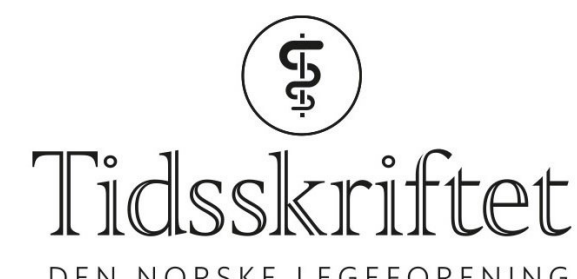

DEN NORSKE LEGEFORENING

\title{
Rettelse: Vannlatingsforstyrrelser hos barn - en praktisk tilnærming
}

RETTELSE

ANINE LIE

ANN CHRISTIN GJERSTAD

VIBEKE FOSSUM

CATHRINE TEIGEN

HANS SKARI

PETRA ADEN

ANNA BJERRE

Tidsskr Nor Legeforen 2020; 140: 155-9.

I Tidsskriftet nr. 2/2020, s. 157 skal det stå: I tre av fire tilfeller er nattlig polyuri, dvs. nattlig urinproduksjon $>130$ \% av forventet blærekapasitet, årsaken. I tabell 2 skal det stå: Nattlig polyuri: Nattlig urinproduksjon $>130 \%$ av forventet blærekapasitet. Dessuten skal det i figur 1 stå: Nattlig polyuri (>130\% av forventet blærekapasitet).

Vi beklager feilen, den er rettet på nett.

Publisert: 4. mai 2020. Tidsskr Nor Legeforen. DOI: 10.4045/tidsskr.20.040o

(C) Tidsskrift for Den norske legeforening 2020. Lastet ned fra tidsskriftet.no 